\title{
General Survey of Diabetic Features of Yellow KK Mice
}

\author{
HisASHi IWATSUKA, AKIO SHINO AND ZIRo SUZUOKI \\ Biological Research Laboratories, Research and Development \\ Division, Takeda Chemical Industries, Ltd., Osaka
}

\begin{abstract}
Synopsis
Yellow KK mice, carrying the yellow obese gene $\left(\mathrm{A}^{\mathrm{y}}\right)$, developed marked adiposity and diabetic symptoms in comparison with their control littermates, black KK mice. The blood glucose and circulating insulin levels were increased progressively from 5 weeks of age in yellow KK mice. Age dependent alterlations were also observed in pancreas and kidney. Namely, degranulation and glycogen infiltration of B cells, first observed at 5 weeks of age, were followed by hypertrophy and central cavitation of islets. Renal glomerular changes, which were very similar to diffuse or exudative type of sclerosis in human diabetes, were also recognized in the mice at 16 weeks of age. These changes, though less remarkable, were also noted in their control littermates older than 16 weeks of age. Some metabolic defects were developed, as demonstrated by in vitro experiments. At younger age, lipogenesis by liver and adipose tissue was increased in yellow KK mice, but there was no noticeable difference in glucose oxidation by adipose tissue between both mice. Insulin sensitivity of adipose tissue was decreased with age in both mice, especially in yellow KK mice being reduced more remarkably to its complete loss at 16 weeks of age. These findings indicate that the yellow obese gene not only induces adiposity but also accelerates development of diabetic traits of $\mathrm{KK}$ mice. A possible mechanism for the observed diabetogenic action of the gene will be discussed.
\end{abstract}

KK mouse is one of the inbred strains established by Kondo et al. (1957) from Japanese native mice. Since Nakamura (1962) identified this strain as a spontaneous diabetic animal, several investigators have reported many diabetic traits such as impaired tolerance to glucose (Nakamura, 1962), moderate hyperglycemia (Nakamura, 1962), insulin resistance of peripheral tissue (Tsuchida, 1966; Dulin, 1967), hyperinsulinemia (Dulin, 1967) and renal glomerular changes (Treser et al., 1968). A genetic study of KK mice indicated that diabetic traits were inherited by polygenes (Nakamura and Yamada, 1963). Nishimura (1967), one of Kondo's coworkers transferred the yellow obese gene $\left(\mathrm{A}^{\mathrm{y}}\right)$ into KK mice by the repeated crossing of yellow obese mice and $\mathrm{KK}$ mice. A congenic strain of KK mice, thus established, has been named yellow $\mathrm{KK}$ or $\mathrm{KKA}^{\mathrm{y}}$ mice.

It has been widely recognized in clinical

Received for publication February 20, 1970 medicine that obesity, hyperinsulinism and diabetes are closely related to each other. Recently, these associated phenomena have been found in some diabetic animals. Nutritional factors, which induced obesity, intensified the development of diabetes in the Wellesley hybrid mice (Cahill et al., 1967) and sand rats (Miki et al., 1967). In the present studies diabetic features of yellow KK mice are compared with those of control KK mice to elucidate the effects of genetical obesity $\left(\mathrm{A}^{\mathrm{y}}\right.$ gene) upon the diabetic traits of KK mice.

\section{Materials and Methods}

Animals: Yellow KK* mice were bred by mating female $\mathrm{KK}$ mice (aa, BB, cc) with male yellow KK

* Yellow $\mathrm{KK}$ mice of $\mathrm{F}_{11}$ generation from the first cross between yellow obese mice and KK mice were introduced to our mice stock through the courtesy of Dr. K. Kondo, Faculty of Agriculture, Nagoya University, Nagoya, Japan. 
mice $\left(\mathrm{A}^{\mathrm{y}} \mathrm{a}, \mathrm{BB}, \mathrm{Cc}\right)$. Their offsprings were classified into the following four groups: 1 . yellow $\mathrm{KK}$ mice $\left(\mathrm{A}^{\mathrm{y}} \mathrm{a}, \mathrm{BB}, \mathrm{Cc}\right)$, referred to $\mathrm{KKA}^{\mathrm{y}}, 2$. albino $\mathrm{KKA}^{\mathrm{y}}$ mice $\left(A^{y} a, B B, c c\right), 3$. black KK mice (aa, $\left.B B, C c\right)$, 4. albino $\mathrm{KK}$ mice (aa, BB, cc), identical with the original $\mathrm{KK}$ mice. In the present study, black $\mathrm{KK}$ mice were used as controls, because albino mice consisted of mice with two different genotypes. All mice were bred and kept under the specific pathogen free condition. Mice were maintained in individual metal cages and fed a usual laboratory chow diet (CE 2, Japan Clea Inc., Tokyo).

Chemical procedures: Blood samples were obtained from the orbital vein plexus with capillary glass. Blood glucose was estimated by glucose oxidase method (Krebs et al., 1964). Urinary glucose was detected with Labstix ${ }^{\circledR}$ (Ames Company Co.). Plasma insulin was determined by an immunological procedure, as described by Hales and Randle (1963). For this purpose, "reference standard insulin" of United States of Pharmacopeia was used as a standard, and the insulin ${ }^{-125}$ I immunoassay kit was purchased from The Radiochemical Center, Amersham, England. The glucose tolerance test was performed on mice made to fast for 20 hours. Glucose in $10 \%$ solution (w/v) was loaded by intraperitoneal injection at a dose of $1 \mathrm{~g} / \mathrm{kg}$ body weight.

Adipose tissue from epididymal or parametrial fat pads weighing about $100 \mathrm{mg}$ was taken into a 15 $\mathrm{m} l$ flask equipped with a central well. The flask contained $1 \mathrm{~m} l$ of Krebs-Ringer bicarbonate buffer containing $20 \mu$ moles of glucose $\left(0.05 \mu \mathrm{Ci}\right.$ of glucose- $1-^{14}$ C) and $2 \mathrm{mg}$ of gelatin with or without insulin. The flasks were gassed with $95 \% \mathrm{O}_{2}-5 \% \mathrm{CO}_{2}$ mixture, capped with rubber stoppers and then shaken $(80$ strokes $/ \mathrm{min}$ ) at $37^{\circ} \mathrm{C}$ for 90 minutes. Thereafter, incubation was terminated by addition of $0.5 \mathrm{~m} l$ of 1 $\mathrm{N} \mathrm{H}_{2} \mathrm{SO}_{4}$ through rubber stoppers. For trapping evolved ${ }^{14} \mathrm{CO}_{4}, 0.4 \mathrm{~m} l$ of Hyamine ${ }^{\circledR} \times 10$ (Packard Instrument $\mathrm{Co}$.) was injected into central wells.

For determination of lipogenesis, about $100 \mathrm{mg}$ adipose tissue was incubated in a $25 \mathrm{~m} l$ flask, containing $40 \mu$ moles glucose, $4 \mathrm{mg}$ gelatin, $8 \mu$ moles sodium acetate $\left(0.1 \mu \mathrm{Ci}\right.$ of acetate- $\left.1-{ }^{14} \mathrm{C}\right)$ in $2 \mathrm{ml}$ of Krebs-Ringer bicarbonate buffer with or without added insulin. After the incubation as described above, tissues were transferred into $3 \mathrm{~m} l$ of alcoholic $\mathrm{KOH}$ solution and saponified. Fatty acids were extracted with petroleum ether after acidification by addition of $6 \mathrm{~N} \mathrm{HCl}$.

About $50 \mathrm{mg}$ of liver slices were placed in a $25 \mathrm{ml}$ flask with $2 \mathrm{ml}$ of Hastings' medium (Hastings et al., 1952) containing $40 \mu$ moles of glucose $(1 \mu \mathrm{Ci}$ of glucose-U $-{ }^{14} \mathrm{C}$ ). In some experiments, liver slices were incubated in $2 \mathrm{~m} l$ of Hastings' medium containing 40 $\mu$ moles of glucose and $8 \mu$ moles of Na-acetate $(1 \mu \mathrm{Ci}$ of acetate- $\left.1-{ }^{14} \mathrm{C}\right)$. Conditions for incubation were the same as those described above. Liver slices incubated with glucose-U- $-{ }^{14} \mathrm{C}$ were digested in $1 \mathrm{~m} l$ of $30 \%$ $\mathrm{KOH}$ solution, and glycogen was isolated by addition of ethanol. Fatty acids of liver slices incubated with acetate- $1-{ }^{14} \mathrm{C}$ were isolated by the same procedure described above.

Radioactivity was determined in a liquid scintillation spectrometer (Tri-Carb 3214, Packard Instrument Co.). Radioactivity in fatty acids or carbon dioxide fraction was estimated in a toluene scintillation fluid. To estimate radioactivity in glycogen, a Carb-o-Sil dioxane system was employed, as described by Miki et al. (1967). Correction for quenching was made by counting before and after addition of internal standards.

Histological procedures: The aldehyde fuchsin technique (Gomori, 1950) was used to stain B granules in the islets of pancreas fixed in Bouin's solution. For identification of glycogen deposits, periodic acid Schiff (PAS) staining was used on pancreas fixed in Rossman solution. Kidney was fixed in $10 \%$ formalin solution and subjected to PAS and hematoxylin eosin stainings.

\section{Results}

\section{Body weight and adipose tissue weight}

Male yellow KK mice showed no difference in the growth as compared with their control littermates, black KK mice, whereas female yellow KK mice showed greater body weight gain (Table 1). In yellow KK mice, adipose tissue weight increased with age and reached the maximum at 10 weeks of age. In their control littermates, it increased only at 16 weeks of age (Table 1). This result shows that adiposity occurred earlier in yellow KK mice than in their control littermates.

\section{Blood glucose and urinary glucose}

Blood glucose level was higher in yellow KK mice than in their control littermates (Table 1). It increased gradually with age in yellow KK mice, and marked hyperglycemia was established at 16 weeks of age. In their control littermates, blood glucose did not increase with age, and remained at the level of about 
$200 \mathrm{mg} / \mathrm{d} l$ even at 16 weeks of age. Females showed lower level than males in both mice. Examination by Labstix indicated that glucosuria was observed in all of the yellow KK mice, but in none of control mice (Table 1.)

\section{Glucose tolerance test}

Yellow KK and their control littermates showed impaired glucose tolerance (Fig. 1). In both mice, the blood glucose level remained still elevated by far above the fasting level even two hr after glucose administration. No appreciable difference was recognized between both mice in the levels before and after the glucose loading, in spite of differences as manifested in the degree of hyperglycemia and the incidence of glucosuria.

\section{Plasma insulin level and insulinogenic index}

Plasma immunoreactive insulin (IRI) was

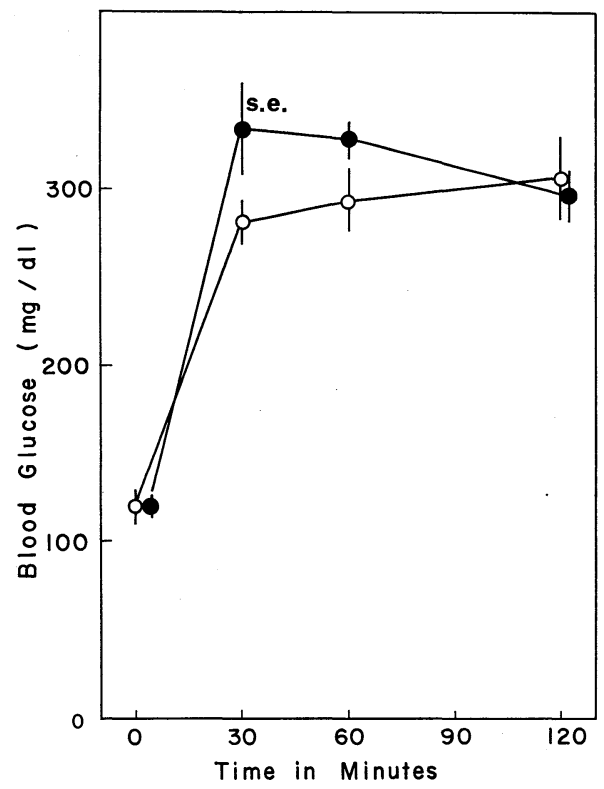

Fig. 1. Glucose tolerance test of yellow $\mathrm{KK}$ mice and their control littermates. Mice were 16 to 18 weeks old. They were made to fast for $20 \mathrm{hr}$ and followed by intraperitoneal glucose injection $(1 \mathrm{~g} / \mathrm{kg})$.

Open circle: yellow KK mice weighed $34 \mathrm{~g}$ ( $\mathrm{n}=$ 13 , 웅, 우7), closed circle: black KK mice weighed $29 \mathrm{~g}(\mathrm{n}=11$, 今 4 , 우7). determined on fed mice at 10 and 16 weeks of age (Fig. 2). The IRI level was markedly elevated in yellow KK mice. There was found a trend for IRI level to increase with age in both mice. The insulinogenic index, ratio of plasma IRI to blood glucose level, was calculated on both mice cited in Figure 2. The index of yellow KK mice was markedly more elevated than that of their control littermates. Namely, the average value $1.44 \pm 0.18$ (s.e.), as expressed in $\mu \mathrm{U} / \mathrm{ml}$ per $\mathrm{mg} / \mathrm{d} l$, for the former, and $0.323 \pm 0.054$ for the latter. As shown in Figure 3, there is a correlation between plasma IRI and blood glucose, and most yellow $\mathrm{KK}$ mice showed higher values than 0.5 .

Adipose tissue metabolism and response to

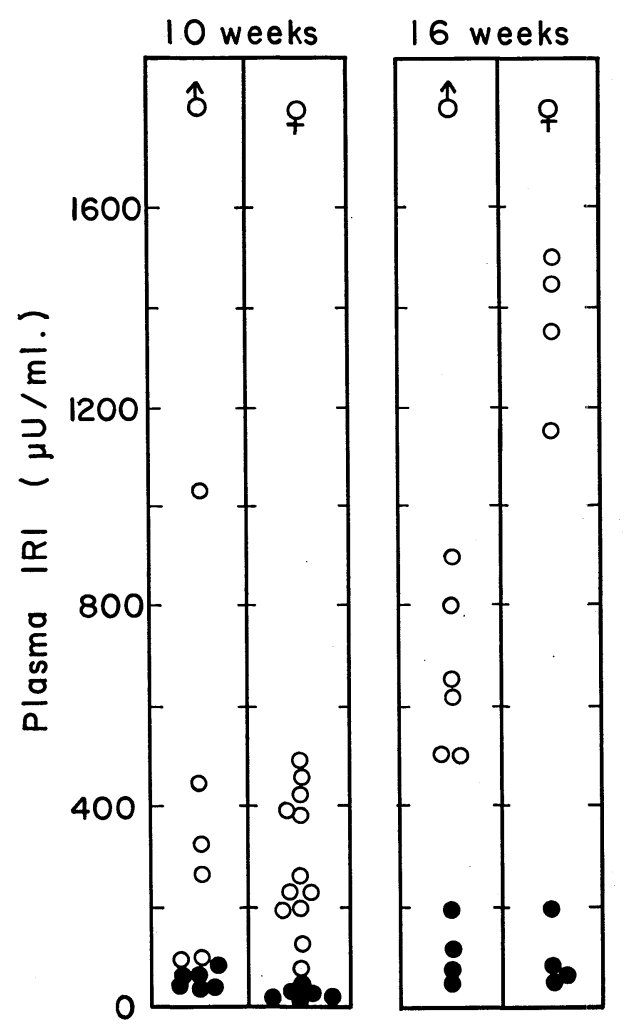

Fig. 2. Plasma immunoreactive insulin level of yellow KK mice and their control littermates. Open circle: yellow KK mice, closed circle: control littermates. 
Table 1. General features of yellow KK mice

\begin{tabular}{|c|c|c|c|c|c|c|}
\hline \multirow[b]{2}{*}{$\begin{array}{c}\text { Age } \\
\text { (wks) }\end{array}$} & \multicolumn{6}{|c|}{ Yellow KK mice } \\
\hline & Sex & $\begin{array}{c}\text { Body } \\
\text { weight* } \\
\text { (g) }\end{array}$ & $\begin{array}{c}\text { Blood } \\
\text { glucose* } \\
(\mathrm{mg} / \mathrm{d} l)\end{array}$ & Glucosuria & $\begin{array}{l}\text { Degran- } \\
\text { ulation } \\
\text { of B } \\
\text { cell } \\
\end{array}$ & $\begin{array}{l}\text { Adipose } \\
\text { tissue } * * * \\
\text { weight } \\
\text { (g) }\end{array}$ \\
\hline \multirow[t]{6}{*}{5} & $\hat{o}$ & 30 & 228 & + & + & 1.00 \\
\hline & & 27 & 278 & + & + & 0.86 \\
\hline & & 30 & 230 & + & + & 0.78 \\
\hline & & 30 & 297 & + & + & 0.98 \\
\hline & & 27 & 266 & + & + & 0.70 \\
\hline & & $29 \pm 0.7$ & $260 \pm 14$ & & & $0.86 \pm 0.06$ \\
\hline \multirow{6}{*}{10} & $\hat{0}$ & 33 & 342 & + & + & 1.28 \\
\hline & & 32 & 264 & + & + & 1.06 \\
\hline & & 35 & 396 & + & + & 1.32 \\
\hline & & 33 & 280 & + & + & 1.07 \\
\hline & & 32 & 315 & + & + & 0.99 \\
\hline & & $33 \pm 0.5$ & $319 \pm 23$ & & & $1.14 \pm 0.06$ \\
\hline \multirow{5}{*}{16} & 今 & 40 & 710 & + & + & 1.21 \\
\hline & & 38 & 428 & + & + & 0.85 \\
\hline & & 41 & 556 & + & + & 1.03 \\
\hline & & 36 & 525 & + & + & 1.09 \\
\hline & & $39 \pm 1.1$ & $554 \pm 58$ & & & $1.05 \pm 0.07$ \\
\hline \multirow[t]{5}{*}{10} & 우 & 33 & 198 & + & + & 3.30 \\
\hline & & 34 & 188 & + & + & 2.68 \\
\hline & & 33 & 200 & + & + & 3.55 \\
\hline & & 35 & 276 & + & + & 3.29 \\
\hline & & $34 \pm 0.5$ & $216 \pm 20$ & & & $3.20 \pm 0.19$ \\
\hline \multirow[t]{5}{*}{16} & 우 & 46 & 530 & + & + & 4.00 \\
\hline & & 43 & 406 & + & + & 3.30 \\
\hline & & 43 & 450 & + & + & 4.00 \\
\hline & & 38 & 380 & + & + & 3.20 \\
\hline & & $43 \pm 1.7$ & $441 \pm 33$ & & & $3.62 \pm 0.22$ \\
\hline
\end{tabular}

* Mean \pm s.e. $\quad * *$ Epididymal or parametrial fat pads.

Table 2. Response of adipose

\begin{tabular}{|c|c|c|c|c|c|}
\hline \multirow{2}{*}{\multicolumn{2}{|c|}{$\begin{array}{l}\text { Age and sex } \\
\text { (weeks) }\end{array}$}} & \multicolumn{2}{|c|}{$5 \hat{\circ}$} & \multicolumn{2}{|r|}{ 10今! } \\
\hline Mouse & & Yellow KK & Black KK & Yellow KK & Black KK \\
\hline $\mathbf{N}$ & & 5 & 5 & 5 & 5 \\
\hline \multicolumn{6}{|c|}{$\begin{array}{l}\text { Glucose-1-14 } \mathrm{C} \text { oxidation* } \\
\text { Insulin concentration }\end{array}$} \\
\hline $0 \mu \mathrm{U} / \mathrm{m} l$ & (A) & $50.5 \pm 3.3$ & $57.1 \pm 5.4$ & $54.6 \pm 3.5$ & $50.0 \pm 7.5$ \\
\hline & (B) & $70.5 \pm 4.9$ & $90.0 \pm 12.3$ & $63.9 \pm 8.5$ & $111.0 \pm 18.0$ \\
\hline $10^{4}$ & & $122.7 \pm 14.2$ & $132.1 \pm 21.8$ & $143.8 \pm 18.6$ & $221.1 \pm 48.3$ \\
\hline \multicolumn{6}{|c|}{$\begin{array}{l}\text { Lipogenesis from acetate- } 1-{ }^{14} \mathrm{C}^{* *} \\
\text { Insulin concentration }\end{array}$} \\
\hline 0 & (C) & $22.4 \pm 2.9$ & $8.5 \pm 1.6$ & $33.4 \pm 1.3$ & $14.2 \pm 1.3$ \\
\hline $10^{3}$ & (D) & $39.4 \pm 5.9$ & $24.4 \pm 5.7$ & $47.0 \pm 11.1$ & $27.1 \pm 4.2$ \\
\hline \multicolumn{6}{|c|}{$\begin{array}{l}\text { Acetate/glucose ratio } \\
\text { Insulin concentration }\end{array}$} \\
\hline 0 & $(\mathrm{C} / \mathrm{A})$ & 0.444 & 0.149 & 0.610 & 0.282 \\
\hline $10^{3}$ & (D/B) & 0.560 & 0.287 & 0.747 & 0.242 \\
\hline
\end{tabular}

* Mean \pm s.e. $\mathrm{m} \mu$ moles glucose oxidized to $\mathrm{CO}_{2} / 100 \mathrm{mg}$ wet tissue $/ 90 \mathrm{~min}$.

** Mean \pm s.e. $\mathrm{m} \mu$ moles acetate incorporated into fatty acids $/ 100 \mathrm{mg}$ wet tissue $/ 90 \mathrm{~min}$. 
and their control littermates, black KK mice

\begin{tabular}{|c|c|c|c|c|}
\hline \multicolumn{5}{|c|}{ Black KK mice } \\
\hline $\begin{array}{l}\text { Body } \\
\text { weight* } \\
\text { (g) }\end{array}$ & $\begin{array}{l}\text { Blood } \\
\text { glucose* } \\
(\mathrm{mg} / \mathrm{d} l)\end{array}$ & Glucosuria & $\begin{array}{l}\text { Degran- } \\
\text { ulation } \\
\text { of B } \\
\text { cell } \\
\end{array}$ & $\begin{array}{l}\text { Adipose } \\
\text { tissue*'** } \\
\text { weight } \\
\text { (g) }\end{array}$ \\
\hline 28 & 264 & - & - & 0.75 \\
\hline 28 & 197 & - & - & 0.60 \\
\hline 27 & 207 & - & - & 0.68 \\
\hline 29 & 203 & - & - & 0.79 \\
\hline 29 & 195 & - & - & 0.68 \\
\hline $28 \pm 0.4$ & $213 \pm 13$ & & & $0.70 \pm 0.03$ \\
\hline 31 & 206 & - & - & 0.58 \\
\hline 33 & 212 & - & - & 0.65 \\
\hline 29 & 190 & - & - & 0.65 \\
\hline 32 & 230 & - & - & 0.66 \\
\hline 32 & 250 & - & - & 0.59 \\
\hline $31 \pm 0.7$ & $218 \pm 10$ & & & $0.63 \pm 0.02$ \\
\hline 36 & 200 & - & \pm & 1.06 \\
\hline 40 & 296 & - & \pm & 1.48 \\
\hline 36 & 252 & - & \pm & 1.06 \\
\hline 36 & 209 & - & \pm & 0.74 \\
\hline $37 \pm 1.0$ & $239 \pm 22$ & & & $1.09 \pm 0.15$ \\
\hline 27 & 151 & - & - & 1.12 \\
\hline 27 & 215 & - & - & 1.24 \\
\hline 26 & 178 & - & - & 1.14 \\
\hline 25 & 148 & - & - & 0.90 \\
\hline $26 \pm 0.5$ & $173 \pm 16$ & & & $1.10 \pm 0.07$ \\
\hline 36 & 256 & - & - & 3.30 \\
\hline 33 & 154 & - & - & 2.20 \\
\hline 37 & 172 & - & - & 2.50 \\
\hline 35 & 212 & - & - & 2.12 \\
\hline $35 \pm 0.9$ & $198 \pm 23$ & & & $2.53 \pm 0.26$ \\
\hline
\end{tabular}

tissue to insulin in vitro

\begin{tabular}{cccccc}
\hline & \multicolumn{2}{c}{$10 \hat{0}$} & \multicolumn{2}{c}{10 우 } & \multicolumn{2}{c}{10 우 } \\
\hline Yellow KK & Black KK & Yellow KK & Black KK & Yellow KK & Black KK \\
\hline 5 & 5 & 5 & 5 & 5 & 5 \\
\hline & & & & & \\
$77.1 \pm 9.1$ & $48.2 \pm 1.6$ & $76.6 \pm 9.9$ & $49.9 \pm 2.2$ & $78.8 \pm 4.6$ & $54.4 \pm 3.2$ \\
$69.8 \pm 3.3$ & $67.1 \pm 14.4$ & $149.0 \pm 9.0$ & $199.0 \pm 41.0$ & $73.9 \pm 5.9$ & $132.1 \pm 13.9$ \\
$78.1 \pm 6.4$ & $116.0 \pm 6.1$ & $178.0 \pm 24.0$ & $191.0 \pm 28.0$ & $78.7 \pm 6.0$ & $163.4 \pm 23.5$ \\
& & & & & \\
$28.1 \pm 3.7$ & $24.4 \pm 3.3$ & $75.3 \pm 4.7$ & $46.5 \pm 4.3$ & $63.2 \pm 8.2$ & $51.1 \pm 15.3$ \\
$25.5 \pm 3.4$ & $39.5 \pm 3.9$ & $98.4 \pm 9.3$ & $80.5 \pm 10.0$ & $62.3 \pm 9.4$ & $94.6 \pm 25.5$ \\
& & & & & \\
0.365 & 0.500 & 0.975 & 0.815 & 0.800 & 0.945 \\
0.366 & 0.599 & 0.667 & 0.402 & 0.845 & 0.715 \\
\hline
\end{tabular}




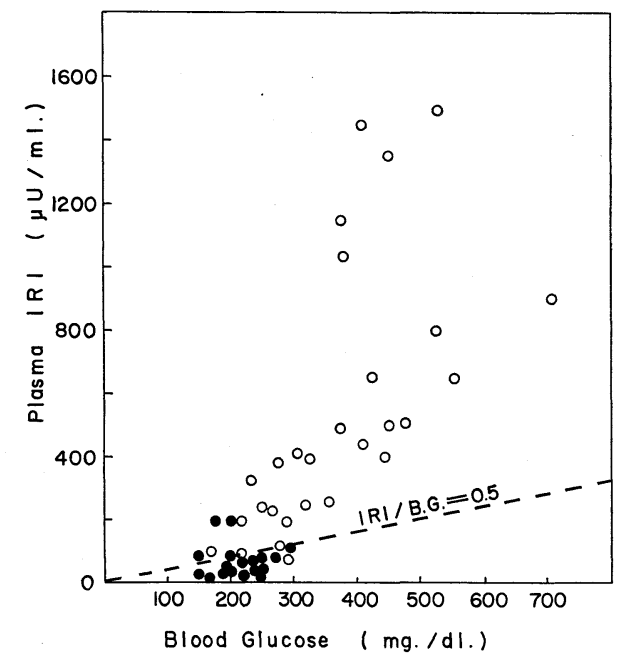

Fig. 3. Correlation of blood glucose level with plasma immunoreactive insulin level.

Open circle: yellow KK mice, closed circle: control littermates. The mice cited in Fig. 2 were used.

\section{insulin}

Glucose- $-1-{ }^{14} \mathrm{C}$ oxidation by adipose tissue of yellow $\mathrm{KK}$ mice was not impaired, but rather predominant over that of their control littermates (Table 2). The rate of oxidation in the presence of insulin was higher in the control mice than in yellow KK mice. Response to insulin, expressed by increment or per cent increase of the activity, was diminished with age. The depression of the insulin sensitivity was more remarkable in yellow KK mice. Namely insulin sensitivity was significantly impaired at 10 weeks of age and completely lost at 16 weeks of age. The response observed in yellow $\mathrm{KK}$ mice between 5 and 10 weeks old was of the same extent as that of the controls at 16 weeks of age.

In yellow KK mice, lipogenesis from acetate by adipose tissue was elevated at 5 weeks of age and this enhanced activity was kept until 16 weeks of age (Table 2). Lipogenesis of control mice was increased with age to attain the same level as that observed in yellow $\mathrm{KK}$ mice. At younger age, there was no difference between both mice in insulin sensitivity ex- pressed by increment of the activity but no significant response to insulin was observed in 16-week-old yellow KK mice.

The ratio of lipogenesis from acetate and oxidation of glucose (acetate/glucose ratio) may reflect a metabolic profile of the adipose tissue (Table 2). Higher ratio was observed in younger yellow KK mice and older control mice whose adipose tissue was already hypertrophed. The result suggests that the development of adiposity is closely related to the predominance of lipogenesis over glucose metabolism. These experiments demonstrate that in the adipose tissue metabolism younger yellow KK mice have comparable profiles to older control mice.

\section{Liver metabolism}

Acetate incorporation into fatty acids by liver slices was elevated in both mice at 16 weeks of age. But lipogenic activity in yellow KK mice, especially at younger age, was significantly higher than that in the controls (Table 3). In contrast to lipogenesis, glycogen synthesis by liver slices showed no noticeable difference between both mice (Table 3).

\section{Histological findings}

Pancreas and kidney showed remarkable abnormalities with advance of diabetic state in yellow KK mice. The number of pancreatic islets of yellow KK mice did not significantly differ from that of the controls. Degranulation of B cells was observed in pancreas of yellow KK mice, irrespectively of age and sex (Fig. 4 and Table 1). Degranulated islets were always infiltrated with fine glycogen granules (Fig. 5). In yellow KK mice, the degranulation and glycogen infiltration of $B$ cells were not always associated with the elevation of blood glucose level (Table 1). Hypertrophic islets appeared in the pancreas of 10 to 16-week-old yellow KK mice, some of which surrounded pancreatic ducts (Fig. 4 and 6). Central cavity formation was observed in enlarged islets (Fig. 4 and 6). Occasionally red blood cells were found in the cavities. In their 
Table 3. Metabolism of acetate $-1-{ }^{14} \mathrm{C}$ and glucose- $\mathrm{U}-{ }^{14} \mathrm{C}$ by liver slices

\begin{tabular}{|c|c|c|c|c|}
\hline $\begin{array}{c}\text { Age } \\
\text { (weeks) sex }\end{array}$ & Mouse & $\mathrm{N}$ & Lipogenesis* & $\begin{array}{c}\text { Glycogen } \\
\text { synthesis** }\end{array}$ \\
\hline \multirow[t]{2}{*}{5 今 } & Yellow KK & 5 & $0.0600 \pm 0.0100$ & $0.355 \pm 0.090$ \\
\hline & Black KK & 5 & $0.0400 \pm 0.0071$ & $0.366 \pm 0.047$ \\
\hline \multirow[t]{2}{*}{$10 \hat{\circ}$} & Yellow KK & 5 & $0.0607 \pm 0.0104$ & $0.485 \pm 0.028$ \\
\hline & Black KK & 5 & $0.0323 \pm 0.0057$ & $0.396 \pm 0.015$ \\
\hline \multirow[t]{2}{*}{16 今 } & Yellow KK & 4 & $0.122 \pm 0.016$ & $0.106 \pm 0.028$ \\
\hline & Black KK & 4 & $0.102 \pm 0.009$ & $0.300 \pm 0.068$ \\
\hline \multirow[t]{2}{*}{10 우 } & Yellow KK & 4 & $0.124 \pm 0.018$ & $0.355 \pm 0.075$ \\
\hline & Black KK & 4 & $0.0450 \pm 0.0050$ & $0.320 \pm 0.020$ \\
\hline \multirow[t]{2}{*}{16 우 } & Yellow KK & 4 & $0.212 \pm 0.031$ & $0.170 \pm 0.045$ \\
\hline & Black KK & 4 & $0.127 \pm 0.021$ & $0.160 \pm 0.075$ \\
\hline
\end{tabular}

* Mean \pm s.e. $\mu$ moles acetate incorporated into fatty acids $/ 100 \mathrm{mg}$ liver $/ 90 \mathrm{~min}$.

** Mean \pm s.e. $\mu$ moles glucose incorporated into glycogen $/ 100 \mathrm{mg}$ liver/90 min.

control littermates, there was observed no significant change (Fig. 7).

Renal glomerular changes were observed in all of the yellow KK mice at 16 weeks of age, but with less incidence in their control littermates of the same age. A common change observed in both mice was the thickening of mesangial matrix resulting from the increased PAS-positive materials (Fig. 8), which resembled the lesion known as human diffuse type sclerosis. In some of these glomeruli of yellow KK mice, was also observed accumulation of eosinophillic materials in outer parts of capillary as well as increase of mesangial matrix (Fig. 9). These lesions were similar to those of exudative type sclerosis. Aside from these glomerular changes, thickening of basement membrane of tubles and Bowman's capsules, dilatation of tubules and the presence of hyaline materials or hyaline cast in the tubules (Fig. 10 and 11) could be also recognized in the kidney of yellow KK mice. Glycogen deposits in tubules were not observed.

Organs other than kidney and pancreas were also subjected to histological examination. Accumulation of fat droplets in liver cells and diminished thickness of adrenal cortex were found in both mice which were already noted on KK mice (Nakamura, 1962).

\section{Discussion}

KK mice have been defined as diabetic animals carrying many diabetic characters resembling those observed in human maturityonset diabetes (Nakamura, 1962; Tsuchida, 1966; Dulin and Gerristen, 1967). Our observations on KK mice are somewhat different from those reported by these investigators. Our KK mice, in so far as they are fed on laboratory chow, show glucose intolerance and insulin resistance, but are neither hyperglycemic nor glucosuric. When fed on synthetic diets which induce obesity, they develop hyperglycemia and glucosuria (our unpublished data). These findings indicate that the mice carry genetic potentials which develop overt diabetes under some specified conditions. The present observation shows that black KK mice are also of chemical diabetes and indistinguishable from albino $\mathrm{KK}$ mice in these diabetic traits. This may be supported by Nakamura's finding that diabetic traits are subject to polygenes in KK mice (Nakamura and Yamada, 1963).

The present studies clarify that yellow KK mice develop severe hyperglycemia and glucosuria associated with both hyperinsulinemia and insulin insensitivity in glucose oxida- 
tion of adipose tissue. These findings indicate that introduction of the yellow obese gene intensifies diabetic traits of $\mathrm{KK}$ mice from chemical diabetes to overt diabetes. The enhancing action of the gene could be explained by assuming that the gene causes primarily hypertrophy of adipose tissue, which in turn diminishes insulin sensitivity of adipocytes. This view can be supported by the findings of Salans et al. (1968). They studied the relationship between insulin sensitivity and cell size in adipocytes and clarified that reduced sensitivity of obese subjects was caused by hypertrophy of the cells. Our unpublished findings that some synthetic diets, which induce obesity, promote the development of diabetes in $\mathrm{KK}$ mice, may be accepted as a phenocopy of diabetes caused by genetical obesity in yellow KK mice. These findings indicate that the development or severity of genetical diabetes of KK mice is affected by obesity, induced genetically or nutritionally.

The insulin resistance of the peripheral tissue may elevate demands for insulin. If yellow $\mathrm{KK}$ mice are the case, the histological changes of pancreatic islets, such as degranulation of B cells and hypertrophy of islets, reflect increased production of insulin to suffice the elevated insulin demand. High insulinogenic index of yellow KK mice indicates the validity of the above compensatory adaptation to lower blood glucose level within normal range. Glycogen infiltration together with degranulation of B cells of non-hyperglycemic yellow KK mice can also indicate such a compensatory regulation, since Carpenter et al. (1967) demonstrate that glycogen infiltration is induced by transitory hyperglycemia.

In contrast to the glucose oxidation, lipogenesis from acetate is elevated in yellow KK mice, possibly due to increased circulating insulin. The acetate/glucose ratio of adipose tissue, which indicates a metabolic profile of the tissue, is higher in younger yellow $\mathrm{KK}$ mice than in their controls. Higher ratios are also recognized in the presence of insulin.
These results indicate higher sensitivity to insulin of lipogenesis than that of glucose oxidation. This feature of yellow KK mice causes predominance of lipogenesis over glucose metabolism which may persist in the living body with elevated insulin level. From these considerations, it is summarized that hyperinsulinemia, accepted as a compensative adaptation to lowered insulin effect in glucose metabolism, would favor activation of lipogenesis rather than glucose metabolism in yellow $\mathrm{KK}$ mice. Consequently, increased lipogenesis could result in development of adiposity, which in turn accelerate development of diabetes, as pointed by Salans et al. (1968).

Glomerular changes found in the present studies can agree with a recent finding of Treser et al. (1968) on aged KK mice. These results show that genetic potential to develop renal vascular changes is common in all of these KK strains. In the present studies, yellow KK mice develop more advanced lesions with respect to their incidence and severity, as compared with control KK mice. Thus, it is apparent that the yellow obese gene intensifies development of renal changes as well as metabolic disturbance which are inherited in KK mice. Our findings are consistent with Warren's description on human prediabetes (Warren, 1966). He stated that development of diffuse type sclerosis or increase of mesangial matrix was recognized in prediabetic state without overt disturbance of metabolism.

Since both KK mice (Nakamura, 1962) and yellow obese mice (Hellerström and Hellman, 1963) are of diabetes, the diabetic genes of KK mice and the yellow obese gene may be expected to exaggerate diabetic state synergically in yellow KK mice. As shown in the present studies, both genes act to strengthen their respective diabetogenesity, but their roles seem different. Namely, diabetes itself is caused primarily by diabetic genes of $\mathrm{KK}$ mice, development of which is influenced by certain specified conditions, for example, 
obesity or ageing process. The yellow obese gene would provide one of such conditions under which overt diabetes is established even at younger age.

Cahill et al. (1967) investigated metabolic disturbance of the Wellesley hybrid mice, which showed hyperglycemia associated with obesity and hyperinsulinemia. They demonstrated the difference in response to insulin in these mice. Namely, hepatic glucokinase responded to the hormone adequately but glucose utilization was quite insensitive as reflected in hyperglycemia. Coleman and Hummel (1967) observed increased activity of lipogenic enzymes such as citrate cleaving enzyme and acetyl-CoA synthetase, in liver of hyperinsulinemic db-mice. These findings indicate that insulin action is not impaired in induction of enzymes, but in acceleration of glucose metablism of peripheral tissues. Highly activated lipogenesis in diabetic animals with hyperinsulinism is ascribed to adequate induction of lipogenic enzymes. This view can agree with our present postulation on development of diabetes in yellow KK mice. Hyperglycemia associated with obesity and hyperinsulinism has been also reported in other diabetic animals, such as obese-hyperglycemic mice (Mayer, 1960), New Zealand obese mice (Sneyd, 1964), and spiny mice (Pictet et al., 1967). The difference in effectiveness of insulin action on metabolic process may be also involved more or less in development of diabetes in these animals.

\section{Acknowledgement}

We are grateful to Dr. K. Kondo and Dr. M. Nishimura, Faculty of Agriculture, Nagoya University, for generous gift yellow $\mathrm{KK}$ breeder mice. We wish to thank Mr. Y. Hamuro, Mr. K. Furuno and Mr. K. Shimakawa in our laboratory for the establishement of the specific pathogen free mice, and routine supply for the present studies. Our thanks are also due to Dr. Kanazawa for his guidans and encouragement.

\section{References}

Cahill, G. F. Jr., E. E. Jones, V. Lauris, J. Steinke and J. S. Soeldner (1967). Diabetologia, 3, 171.

Carpenter, A. M. and A. Lazarow (1967). Diabetes, 16, 493.

Coleman, D. L. and K. P. Hummel (1967). Diabetologia 3, 238.

Dulin, W. E. and G. C. Gerristen (1967). Proc. 6th Congr. Inter. Diabetes Fed., Stockholm.

Gomori, G. (1950). Am. J. Clin. Pathol., 20, 665.

Hales, C. N. and P. J. Randle (1963). Biochem. J., 88, 137.

Hastings, A. B., C-T. Teng, F. B. Nesbett and F. M. Sinex (1952). J. Biol. Chem., 194, 69.

Hellerström, C. and B. Hellman (1963). Metabolism, 12, 527.

Krebs, H. A., C. Dierks and T. Gacoyne (1964). Biochem. J., 93, 112.

Kondo, K., K. Nozawa, T. Tomita and K. Ezaki (1957). Bull. Exp. Animal., 6, 107. (In Japanese)

Mayer, J. (1960). Am. J. Clin. Nut., 8, 712.

Miki, E., A. A. Like, J. Steinke and J. S. Soeldner (1967). Diabetologia, 3, 135.

Nakamura, M. (1962). Proc. Japan. Acad., 38, 348.

Nakamura, M. and K. Yamada, Jr. (1963)., Ibid., 39, 489.

Nishimura, M. (1969) Exp. Animals, (Tokyo), $18,147$.

Pictet, R., L. Orci, A. E. Gonet, C. Rouiller and A. E. Renold (1967). Diabetologia, 3, 188.

Salans, L. B., J. L. Knittle and J. Hirsch (1968). J. Clin. Invest., 47, 153.

Sneyd, J. G. T. (1964). J. Endcrinol., 28, 163.

Treser, G., W. Oppermann, T. Ehrenreich, K. Lange, R. Levine and R. A. CameriniDavalos (1968). Proc. Soc. Exptl. Biol. Med., 129, 820.

Tsuchida, I. (1966). J. Japan Diabetic. Soc., 9, 67. (In Japanese).

Warren, S. Pathology of Diabetes. 4th ed. Lea \& Febiger," p. 228 (1966). 
Fig. 4. Degranulated pancreatic islet of yellow KK mice (16 weeks old, male).

C: central cavity, D: pancreatic duct. Aldehyde fuchsin stain. $\times 270$.

Fig. 5. Glycogen granules in pancreatic islet of yellow KK mice (16 weeks old, male). G: glycogen granule. PAS stain. $\times 1200$.

Fig. 6. Central cavitation in hypertrophic islets of yellow $\mathrm{KK}$ mice (16 weeks old, male). $\mathrm{C}$ : central cavity. Hematoxylin and eosin stain. $\times 150$.

Fig. 7. Well-granulated islet of black KK mice (16 weeks old, male). Aldehyde fuchsin stain. $\times 300$. 
3)

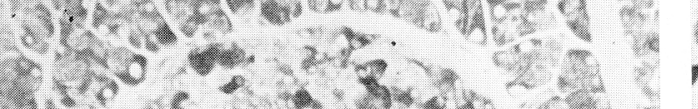

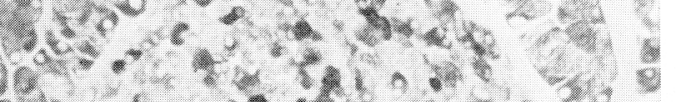

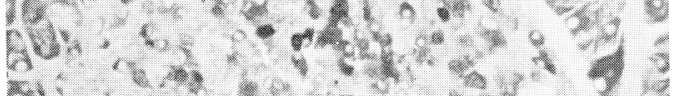

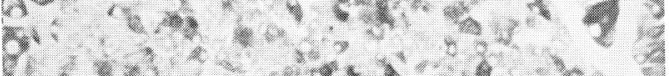

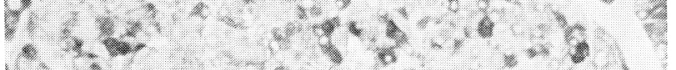
$b^{3}-1: 25$ $4 \sin ^{2} \cos ^{2}+2$

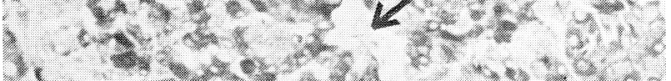

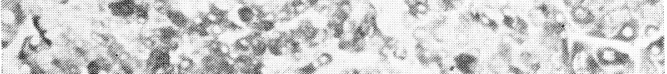

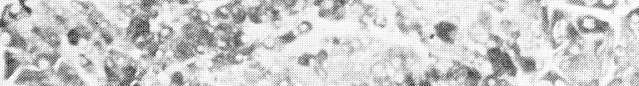

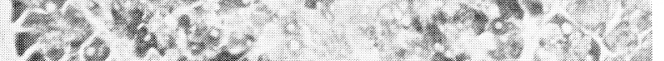

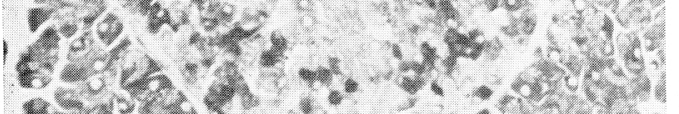

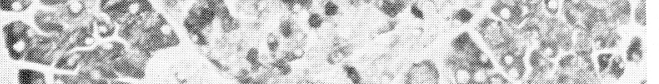

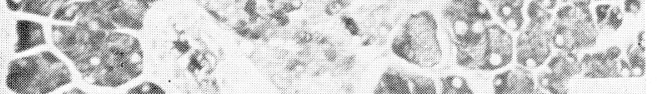

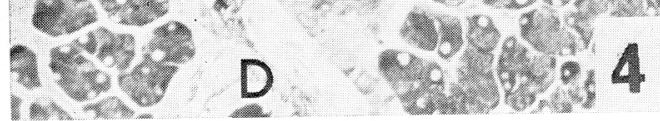

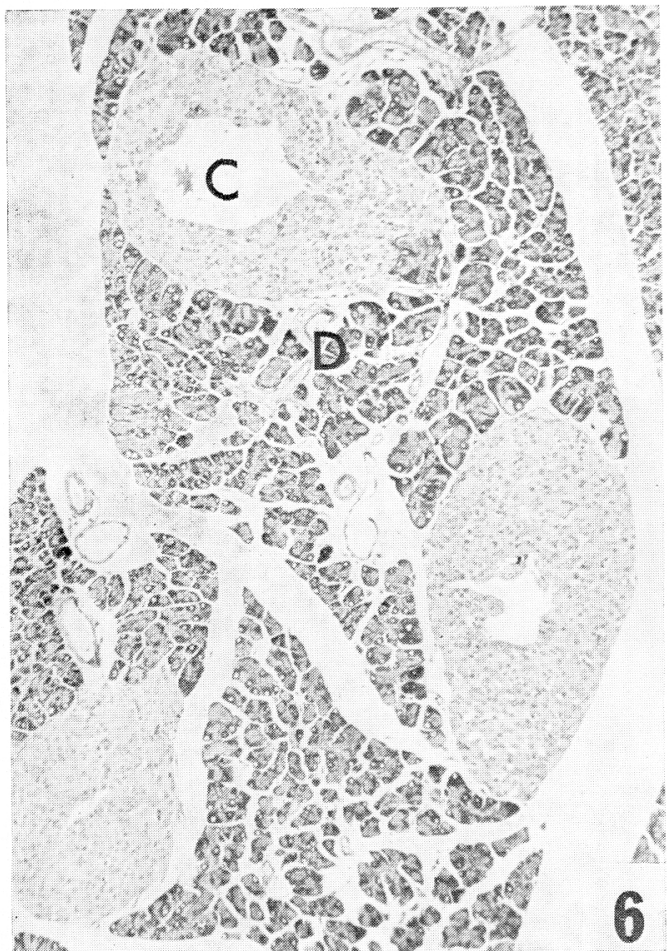

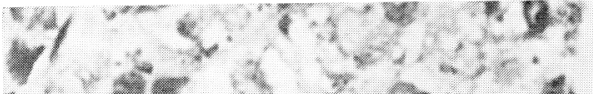

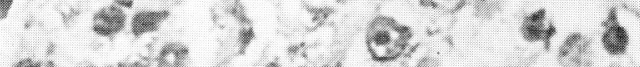

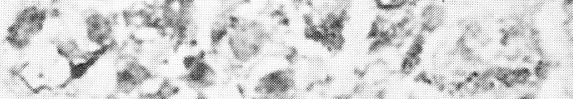

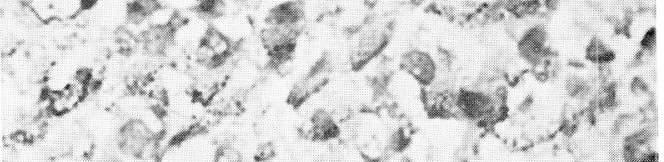
S.

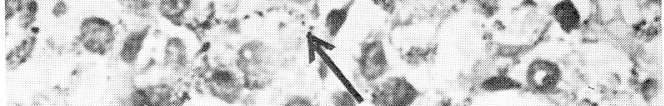
a a G a

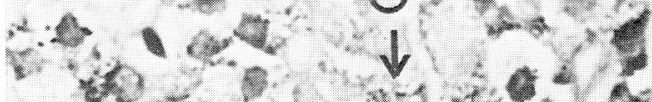
40 4.

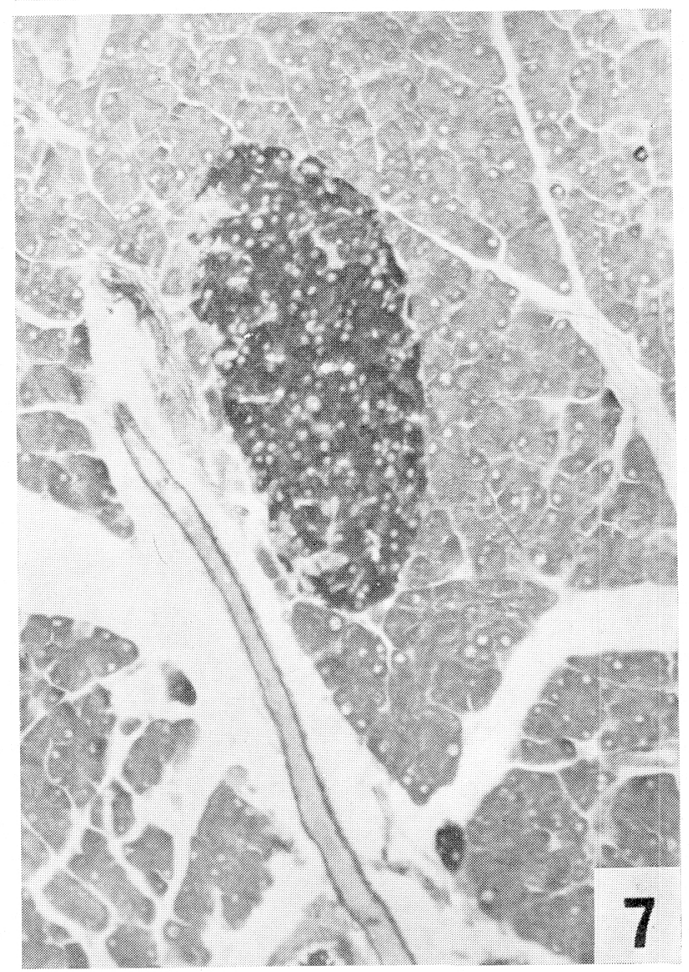


Fig. 8. Diffuse thickening of mesangial matrix. Glomerulus of yellow KK mice (16 weeks old, male). M.M.: mesangial matrix. PAS stain. $\times 1000$.

Fig. 9. Accumulation of eosinophilic material in peripheral parts of capillary. Glomerulus of yellow KK mice (16 weeks old, male).

E: eosinophilic material. Hematoxylin eosin stain. $\times 1000$.

Fig. 10. Thickening of basement membrane of Bowman's capsule. Glomerulus of yellow KK mice (16 weeks old, male).

B.M.: basement membrane. PAS stain. $\times 1000$.

Fig. 11. Thickening of basement membrane of tubules, and hyaline casts in dilated tubules.

B.M.: basement membrane, $\mathrm{H}$ : hyaline cast. Kidney of yellow KK mice (16 weeks old, male). PAS stain. $\times 300$. 

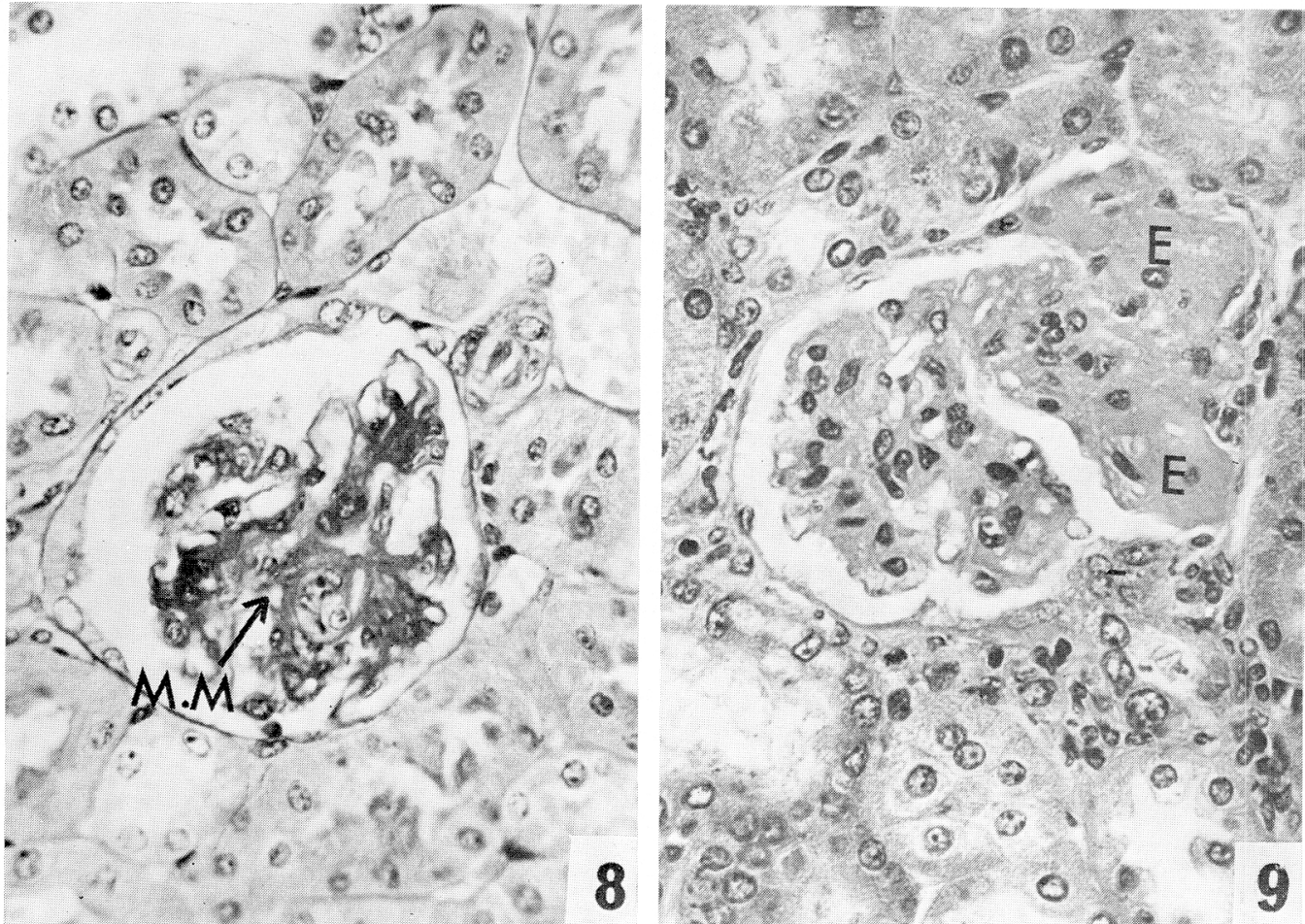

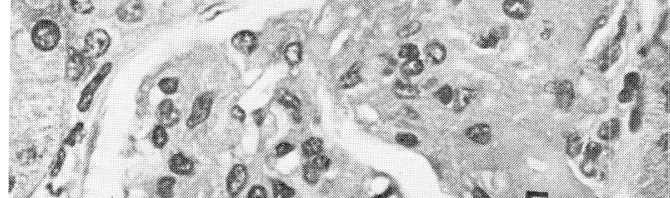

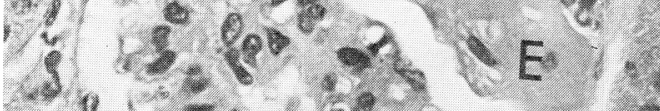
- 20.

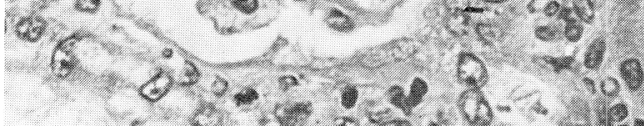
\%

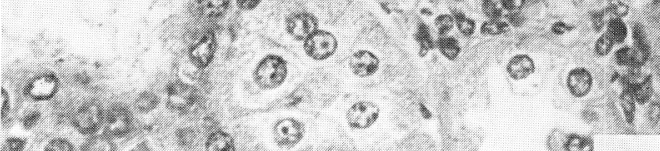

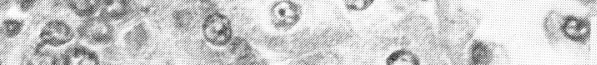
$50-3=0$

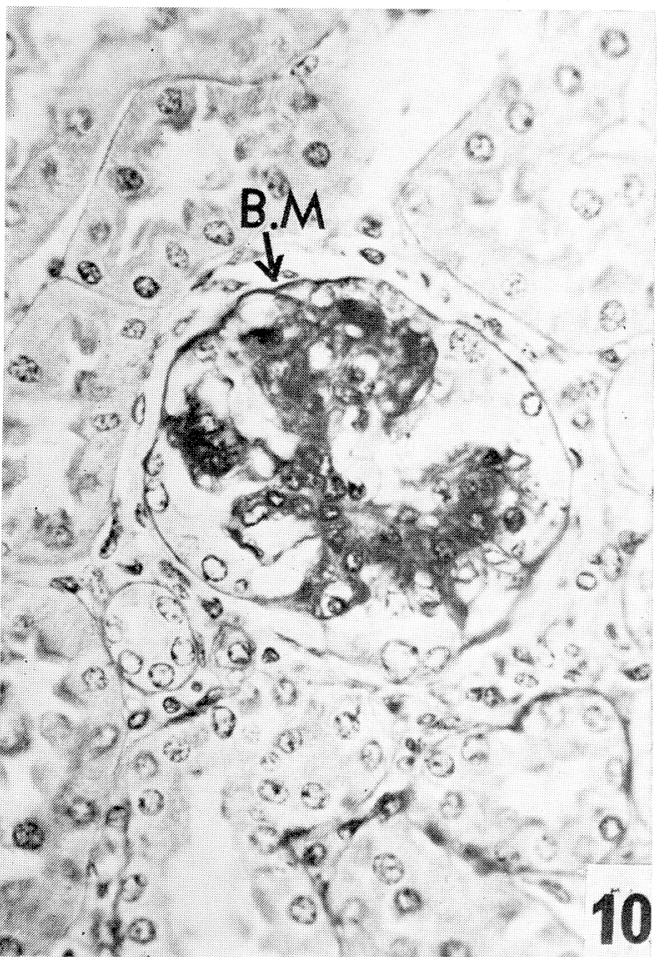

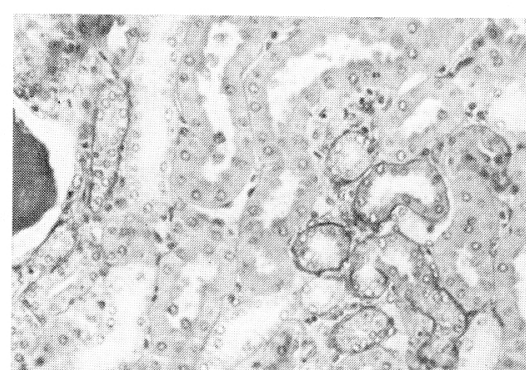

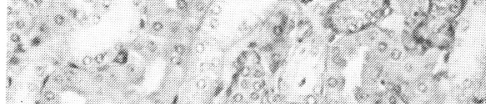
$\mathrm{H}_{-50} \mathrm{~K}$

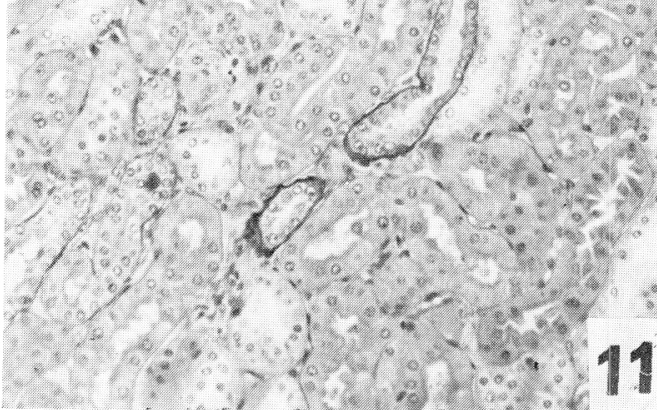

